\title{
EFFECT OF BIOLOGICAL PREPARATION ON CHANGES IN SOIL ORGANIC CARBON AND ITS ENVIRONMENTAL IMPACT APPLYING PRECISION FARMING
}

\author{
Darius Juknevicius $^{1}$, Egidijus Sarauskis ${ }^{1}$, Daiva Rimkuviene ${ }^{1}$, Julija Rukaite ${ }^{1}$, Davut Karayel ${ }^{2}$ \\ ${ }^{1}$ Aleksandras Stulginskis University, Lithuania; ${ }^{2}$ Akdeniz University, Turkey \\ darius.juknevicius11@gmail.com, egidijus.sarauskis@asu.lt,daiva.rimkuviene@asu.lt, \\ julyterukaite31@gmail.com,dkarayel@akdeniz.edu.tr
}

\begin{abstract}
Soil organic carbon is one of the key qualitative soil parameters. I't affects soil vitality, its humus content, microorganism activity, soil $\mathrm{CO}_{2}$ emissions, as well as basic fertilizer needs and plants' ability to source nutrients. According to Christopher and Lal (2007), the carbon (C) cycle is closely related to the nitrogen (N) cycle in plants and soil organic matter. The application of precision farming can aid in determining the exact content of organic carbon in soil and the appropriate carbon - nitrogen ratio for plant growth, digestion and absorption of waste. The aim of this work is to determine the impact of biological preparation on the soil organic carbon content, fertilizer needs, harvest and environment. Experimental research was conducted in Pasvalys district, coordinates 55.920437, 24.212736 (WGS); 3 cases were researched: SC1 - biological preparation "Product 1", SC2 - biological preparation "Product 2"; SC3 - no biological preparation (control). Veris P4000 VIS-NIR equipment was used for this research in order to estimate the soil organic carbon content, electrical conductivity, soil hardness and to do spectral analysis in the 380-2200 nm wavelength range in 0-100 cm depth. Research indicates that in the SC1 case, the soil organic carbon content grew from $1.8 \%$ to $2 \%$, compared to SC3, where the soil organic carbon content change was negative and fell from $2.2 \%$ to 2,09\%. The maximum yield was reached in the SC2 case and resulted in $5.38 \mathrm{t} \cdot \mathrm{ha}^{-1}$, compared to $5.26 \mathrm{t} \cdot \mathrm{ha}^{-1}(\mathrm{SC} 1)$ and $4.37 \mathrm{t} \cdot \mathrm{ha}^{-1}(\mathrm{SC} 3)$.
\end{abstract}

Keywords: biopreparation; fertilizer use; soil organic carbon, $\mathrm{CO}_{2}$.

\section{Introduction}

One of the most important soil components is the amount of organic matter in it.The main element in soil organic matter is carbon [1]. Normally, the change of the amount of soil organic carbon is due to the change of soil active fraction [2].The increase of soil organic carbon improves the soil structure and durability [3; 4].

The results of an experimental research performed in Canada showed that the decrease of soil organic matter by $1.0 \mathrm{Mg} \cdot \mathrm{ha}^{-1}$ in $0-7 \mathrm{~cm}$ soil layer, resulted in a decline in wheat yields by $39 \mathrm{~kg} \cdot \mathrm{ha}^{-1}$ (Lethbridge) and $19 \mathrm{~kg} \cdot \mathrm{ha}^{-1}$ (Hill Spring) [2; 5]. In North Dakota, the USA, the reduction of soil organic carbon by $1.0 \mathrm{Mg} \cdot \mathrm{ha}^{-1}$ in $0-50 \mathrm{~cm}$ soil layer reduced the yields by $26 \mathrm{~kg} \cdot \mathrm{ha}^{-1}$ [6]. Equivalent research in Russia showed that the increase of humus content in soil by $1.0 \%$ resulted in $1 \mathrm{t} \cdot \mathrm{ha}^{-1}$ higher wheat yields [2; 7].

Soil microorganisms are not only important in maintaining the soil structure, but they also perform organic matter degradation, increase the availability of nutrients to plants, and aid in the biochemical cycle [8; 9]. The change in microorganisms can affect the soil $\mathrm{CO}_{2}$ emissions, as well as increase the soil organic carbon losses [10;11]. In addition, high microorganism activity promotes carbon sequestration in soil[12]. Research indicates, that the diversity of soil microbial community is related to the fluctuations of soil organic carbon. Soil enzymes produced by microorganisms are key in the soil organic carbon mineralization process $[8 ; 13]$. Therefore, soil microorganisms and enzymes are vital elements that influence the processes in the soil carbon cycle [8].

Intensive long term use of soil in agriculture results in the change of natural soil processes and soil properties. In order to preserve soil fertility, timely implementation of precision farming and sustainable soil improvement technologies are crucial. The chemical soil improvement method involves increasing the amount of nutrients. Mineral fertilizer application led to a $15.1 \%$ increase in the microbial biomass above levels in unfertilised control treatments. Mineral fertilization also increased soil organic carbon (Corg) content by the average of $12.8 \%$, compared to no mineral fertilizer [14]. When using mineral fertilizers, their nutritional elements may not always be accessible to plants due to certain environmental factors. Biological methods are also used to improve soil, when the goal is to increase the amount of humus and biological nitrogen. Soil biological activity is an important fertility factor both agronomically and ecologically. It is also a sensitive indicator of anthropogenic impact. Soil biological activity is influenced not only by fertilization, but also by cultivating agricultural crops, the impact of which is determined by the amount of plant residues and 
their chemical composition $[15 ; 16]$. A large number of different biological preparations is used to improve plant productivity and resistance, as well as to improve soil properties. Biological preparations encourage nutrient absorption even in extreme conditions[17]. However, there is a lack of research that would explain the way biological preparations influence the amount of humus and organic carbon in soil and how their use affects the demand for fertilizers. Given this dependency, precision farming technologies could be used.

The aim of this work is to identify the change in soil organic carbon levels in wheat crops, when using biological preparations, their effect on fertility, fertilizer needs and the environmental impact.

\section{Materials and methods}

Experimental research was conducted in a 8.00 ha field located in Šedeikoniai, Pušalotas Municipality, Pasvalys District, coordinates: 55.920437, 24.212736 (WGS); height difference (50,600$47,000)-3.6 \mathrm{~m}$. The field in question is predominantly loamy sand.

Soil samples were taken on April 28 and September 9.The field was divided into 9 equal zones: 3 for each case ( 2 biological preparations and 1 control). Each section is $\sim 500 \mathrm{~m}$ long and $20 \mathrm{~m}$ wide. Samples were taken from the same spot in all these sections.

"Dagmar" winter wheat was grown in the field. Test spraying was performed with different preparations: Product 1 composition: molasses and magnesium sulphate based biological product (decrease of $20 \%$ of other used preparations is advised when using this product); Product 2 composition: Bacillus spp., Thiobacillus spp., Azotobacter spp., etc., PGPR spp., mycorrhiza mushrooms, Fe, Zn, S releasing bacteria, seaweed extract, organic matter microorganisms biologically synthesized enzymes, enzymes and enzyme-stimulating substances.

Other preparations used at the farm were sprayed alongside the biopreparations:

SC1 (Product 1): Product $12 \mathrm{l} \cdot \mathrm{ha}^{-1}$, urea $8 \mathrm{~kg} \cdot \mathrm{ha}^{-1}$, magnesium sulphate" AGRO TOP" $4 \mathrm{~kg} \cdot \mathrm{ha}^{-1}$, micro-nutrient fertilizer "LYDERIS Mikro" $800 \mathrm{ml} \cdot \mathrm{ha}^{-1}$, micro-nutrient fertilizer for wheat "SUPLOFOL mikro Z", $800 \mathrm{ml} \cdot \mathrm{ha}^{-1}$, "Cycocel" $800 \mathrm{ml} \cdot \mathrm{ha}^{-1}$, water level $200 \mathrm{l} \cdot \mathrm{ha}^{-1}$.

SC2 (Product 2): Product $21,51 \cdot \mathrm{ha}^{-1}$, urea $10 \mathrm{~kg} \cdot \mathrm{ha}^{-1}$, magnesium sulphate "AGRO TOP" $5 \mathrm{~kg} \cdot \mathrm{ha}^{-1}$, micro-nutrient fertilizer "LYDERIS Mikro" $11 \cdot \mathrm{ha}^{-1}$, micro-nutrient fertilizer for wheat "SUPLOFOL mikro Z"1 1.ha' ${ }^{-1}$, "Cycocel"1 $1 \cdot \mathrm{ha}^{-1}$, water level $200 \mathrm{l} \cdot \mathrm{ha}^{-1}$.

SC3 (Control): urea $10 \mathrm{~kg} \cdot \mathrm{ha}^{-1}$, magnesium sulphate "AGRO TOP" $5 \mathrm{~kg} \cdot \mathrm{ha}^{-1}$, micro-nutrient fertilizer "LYDERIS Mikro" $11 \cdot \mathrm{ha}^{-1}$, micro-nutrient "SUPLOFOL mikro Z"11.ha ${ }^{-1}$, "Cycocel" $11 \cdot$ ha $^{-1}$, water level $2001 \cdot$ ha $^{-1}$.

To estimate the level of nitrogen $\left(\mathrm{N}-\mathrm{NO}_{3}+\mathrm{N}-\mathrm{NO}_{2}+\mathrm{N}-\mathrm{NH}_{4}\right), \mathrm{P}_{2} \mathrm{O}_{5}, \mathrm{~K}_{2} \mathrm{O}$, pH and to identify the granulometric soil composition, soil samples were taken from three $20 \mathrm{~cm}$ deep holes drilled in each section of the field using a $15 \mathrm{~cm}$ diameter soil drill. These 3 samples were then mixedand combined into a single sample $(\sim 0.5 \mathrm{~kg})$.To estimate the level of soil organic carbon, samples were taken from the area, where soil hardness and electrical conductivity was measured, and the hyperspectral imaging analysis was performed $(0-5,5-10,10-15,15-20$ and 20-30 $\mathrm{cm}$ depths) twice in each section of the field $(\sim 0.5 \mathrm{~kg})$. For this, 8 and $15 \mathrm{~cm}$ diameter drills were used.

Veris P4000 machine with a hydraulic metal rod equipped with a 1 square inch nozzle was used to measure soil hardness (Fig. 1). It can measure up to $1.0 \mathrm{~m}$ depth.

All data and graphics for the experiment were organised using MS Excel 2016. Data was analysed using R software. Kruskal-Wallis test (K-W) was used to find any statistically significant differences among the scenarios, the Tukey Contrasts test was employed to test all possible pair-wise differences of means. Also, the t-test was applied to determine any statistically significant differences among seasons.

\section{Results and discussion}

Soil organic carbon affects the ability of the soil to absorb nutrients in the shape that is accessible to plants. Different levels of soil organic carbon influence not only the fertility of cultivated plants, but also the greenhouse gas emissions. Increasing the organic carbon content in the soil can produce the same wheat yield using less mineral fertilizers [18]. 


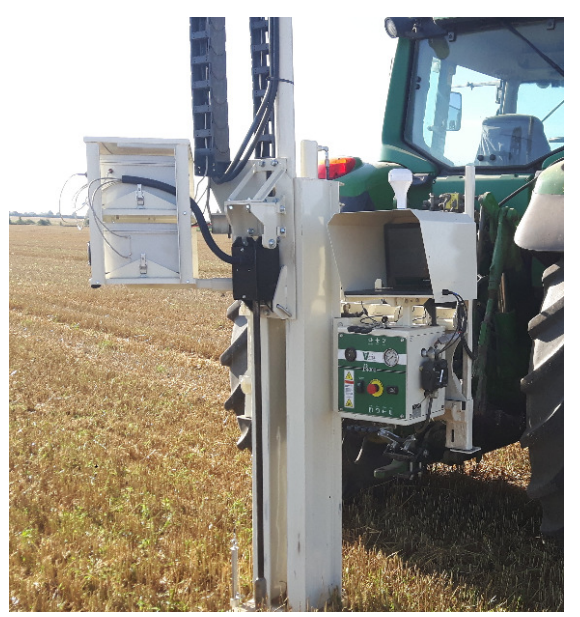

Fig. 1. Veris P4000 VIS-NIR machine

This is achieved through the reduced loss of nitrates in the soil and increased efficiency of fertilizer use[19]. However, because the relationship between the soil organic carbon, fertility and fertilizer use is not clear when using biological preparations, measurements of soil organic carbon levels were done, the results of which are indicated in Fig. 2.

During this research, no substantial differences were observed in the levels of soil organic carbon, but in the case of Product 1 use, $0.18 \%$ increase in soil organic carbon in the depth of $0-35 \mathrm{~cm}$ was detected, meanwhile other cases showed a decrease of $0.1 \%$.

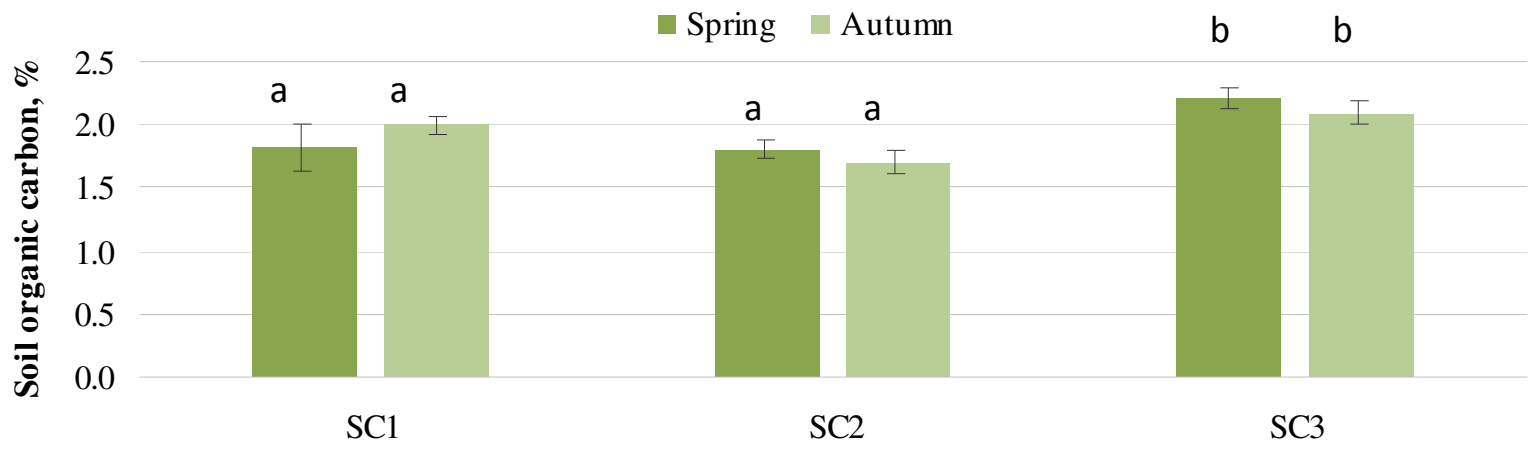

Fig. 2. Fluctuation of soil organic carbon in different scenarios

During the research period, $170 \mathrm{~kg}$ of nitrogen active substance were added to each hectare of soil in the form of mineral fertilizer. It must be noted that in the control case prior to the experiment, the level of nitrogen in soil was the lowest $-\sim 15 \mathrm{~kg} \cdot \mathrm{ha}^{-1}$ less than in other cases, however, during the research period, the following amounts of nitrogen were used: SC1 $-214 \mathrm{~kg} \cdot \mathrm{ha}^{-1}, \mathrm{SC} 2-210 \mathrm{~kg} \cdot \mathrm{ha}^{-1}$, SC3 - $195 \mathrm{~kg} \cdot \mathrm{ha}^{-1}$ (Fig. 3). In the comparison of the aforementioned use of fertilizer and the fertility in the corresponding research scenarios, it can be observed, that when no biological preparation is used, $\sim 5 \mathrm{~kg}$ more $\mathrm{N}$ fertilizer is required for $1 \mathrm{t}$ of yield, i.e. approximately $25 \mathrm{~kg} \mathrm{~N} \cdot \mathrm{ha}^{-1}$ can be saved in each hectare that yields $5 \mathrm{t}$ of crops.



Fig. 3. Levels of nitrogen in different scenarios before first use of fertilizer and after harvesting 
According to the results of this research, it can be concluded that in the SC1 case, because of the increased level of soil organic carbon, the use of nitrogen fertilizer can be lowered by $\sim 25 \mathrm{~kg} \cdot \mathrm{ha}^{-1}$, in turn, decreasing the $\mathrm{CO}_{2}$ emissions during the process of fertilizer production and its use. As stated in IPPC 2014,during the production and application of $1 \mathrm{~kg}$ of nitrogen active substance in the form of fertilizer, $9.14 \mathrm{~kg}$ of $\mathrm{CO}_{2}$-eq, $11.19 \mathrm{~kg} \mathrm{CO}_{2}$-eq of urea and $10.95 \mathrm{~kg} \mathrm{CO}_{2}$-eq of ammonium sulphate gasses are emitted into the atmosphere [20]. Depending on the fertilizer, the emissions during its production and use can be lowered to as much as 228.50-279.75 $\mathrm{kg} \mathrm{CO}_{2}$-eq for each hectare.

Wheat fertility, when biological preparations Product 1 and Product 2 were used, was $5.26 \pm 0.43 \mathrm{t} \cdot \mathrm{ha}^{-1}$ and $5.38 \pm 0.54 \mathrm{t} \cdot \mathrm{ha}^{-1}$, while in the control scenario, it amounted to $4.37 \pm 0.40 \mathrm{t} \cdot \mathrm{ha}^{-1}$, as shown in Fig. 4. Despite the small difference between SC1 and SC2, the fertility increase in both cases proved significant, when compared to the control test. These results were achieved due to the better nutrient absorption and the decreased losses to the groundwater.

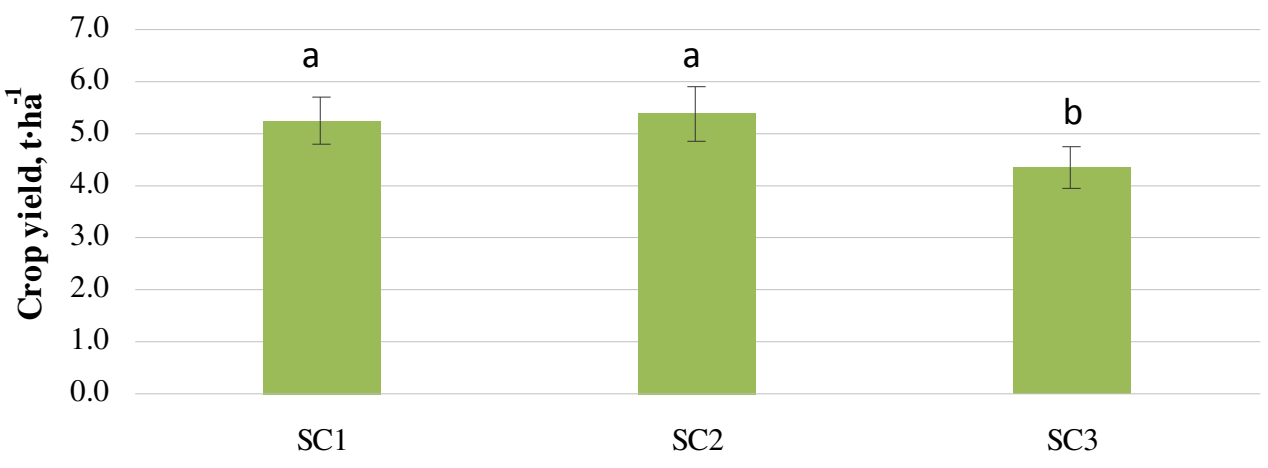

Fig. 4. Wheat fertility in different scenarios

The fluctuation of soil hardness was similar in all scenarios. A comparison of spring and autumn data showed the following results in the depth of $5 \mathrm{~cm}$ : SC1 1.3-2.07 MPa (59\% increase); SC2 1.75$2.42 \mathrm{Mpa}$ (38 \%increase); SC3 1.16-1.14 MPa (2\% decrease). The same tendency prevailed in $30 \mathrm{~cm}$ depth: SC1 4.07-4.81 MPa (18 \% increase); SC2 3.44-4.45 MPa (29 \% increase); SC3 2.79-2.78 MPa ( $0.5 \%$ decrease). These results largely depended on the weather conditions during the tests. The soil was wet and "soft", when samples were taken in spring, while in autumn, it was dry after harvesting. However, the reasons behind the difference in hardness between the cases where biological preparations were used and control are not clear.

When the exact levels of soil organic carbon and nitrogen active substance (nutrition) are known, fertilization maps can be created and used in order to save mineral fertilizers and lessen the environmental impact without any loss of crops.

\section{Conclusions}

1. After the use of different biological preparations on wheat crops, Product 1 proved to have a positive effect on the level of soil organic carbon - an increase of $0.18 \%$ was measured. The other two cases showed a decline.

2. Despite the fluctuation of the organic carbon levels in the soil, in SC1 (Product 1) and SC2 (Product 2), when biological preparations were used, wheat fertility reached $5.26 \pm 0.43 \mathrm{t} \cdot \mathrm{ha}^{-1}$ and $5.38 \pm 0.54 \mathrm{t} \cdot \mathrm{ha}^{-1}$, respectively, and was $0.89-1.01 \mathrm{t} \cdot \mathrm{ha}^{-1}$ higher than in SC3(Control) (its fertility was $\left.4.37 \pm 0.4 \mathrm{t} \cdot \mathrm{ha}^{-1}\right)$.

3. The analysis of the nitrogen content in soil in spring and autumn indicates that different levels of nitrogen active substance were used in different scenarios during the cultivation of crops. SC1 (Product 1) and SC2 (Product 2) cases required $5 \mathrm{~g} \cdot \mathrm{ha}^{-1}$ of nitrogen active substance for $1 \mathrm{t}$ of wheat. Based on this difference, it can be stated that by using biological preparations the same yields can be achieved with less nitrogen fertilizer - approximately $25 \mathrm{~kg} \mathrm{~N} \cdot \mathrm{ha}^{-1}$ less than in the case of SC3 (control).

4. The amount of fertilizer that is saved allows for a decrease of $\mathrm{CO}_{2}$ emissions from 228.5 to $279.75 \mathrm{~kg} \mathrm{CO} \mathrm{Cl}_{2} \mathrm{eq} \cdot \mathrm{ha}^{-1}$, which, compared to the normal $\mathrm{CO}_{2}$ emissions, equals to 7.7-9.4\%. 


\section{References}

[1] Kasel S, Bennettl T. Land-use history, forest conversion, and soil organic carbon in pine plantations and native forests of south eastern Australia // Geoderma. Iss. 3-4, 2007 vol. 137, pp. 401-413.

[2] Lal R. Enhancing crop yields in the developing countries through restoration of the soil organic carbon pool in agricultural lands. Land Degrad. Develop. 17, 2006, pp. 197-209

[3] Feller C., Beare M.H. Physical control of soil organic matter dynamics in tropical land use systems. Geoderma 79, 1997, pp. 49-67.

[4] Haynes R.J., Naidu R. Influence of lime, fertilizer and manure applications on soil organic matter content and soil physical conditions: a review. Nutritient Cycling in Agroecosystems 51, 1998, pp. 139-153.

[5] Larney F.J., Janzen H.H., Olson B.M., Lindwall C.W. Soil quality and productivity response to simulated erosion and restorative amendments.Canadian Journal of Soil Science 80, 2000, pp. 515-522.

[6] Bauer A., Black A.L. Quantification of the effect of soil organic matter content on soil productivity. Soil Science Society of America Journal 58: 1994, pp. 185-193.

[7] Ganzhara N.F. Humus, soil properties and yield. Eurasian Soil Science 31, 1998, pp. 738-745.

[8] Xiao Y., Huangc Z., Lua X. Changes of soil labile organic carbon fractions and their relation to soil microbial characteristics in four typical wetlands of Sanjiang Plain, Northeast China. Ecological Engineering 82, 2015, pp. 381-389.

[9] Douterelo I., Goulder R., Lillie M. Soil microbial community response to land management and depth, related to the degradation of organic matter in English wetlands: implications for the in situ preservation of archaeological remains. Appl. Soil Ecol. 44, 2010, pp. 219-227

[10] Carney K.M., Hungate B.A., Drake B.G., Megonigal J.P. Altered soil microbial community at elevated CO2 leads to loss of soil carbon. Proc. Natl. Acad. Sci. U. S. A. 104, 2007, pp. 4990-4995.

[11] Allison S.D., Wallenstein M.D., Bradford M.A. Soil-carbon response to warming dependent on microbial physiology. Nat. Geosci. 3, 2010, pp. 336-340.

[12] Six J., Frey S.D., Thiet R.K., Batten K.M. Bacterial and fungal contributions to carbon sequestration in agroecosystems. Soil Sci. Soc. Am. J. 70, 2006, pp. 555-569.

[13] Ahn M.Y., Zimmerman A.R., Comerford N.B., Sickman J.O., Grunwald S., Carbon mineralization and labile organic carbon pools in the sandy soils of a North Florida watershed. Ecosystems 12, 2009, pp. 672-685.

[14] Geisseler D., Scow K.M. Long-term effects of mineral fertilizers on soil microorganisms' e A review. Soil Biology \& Biochemistry 75, 2014, pp. 54-63.

[15] Bosi S., Da Ros T., Spalluto G., Prato M. Fullerene derivatives: an attractive tool for biological applications. European journal of medicinal chemistry, 38(11), 2003. pp. 913-923.

[16] Arlauskienė E. Dirvožemio biologinio aktyvumo rodiklių palygnimas. Žemdirbystė: LŽI ir LŽŪU mokslo darbai. Akademija, T. 61, 1998, pp. 72-77.

[17] Jakienè E. Effect of biological products on sugar-beet crop. Žemès ūkio mokslai. T.18, Nr.2, 2011, pp. 64-71.

[18] Aggarwal R.K., Kumar P., Power J.F. Use of crop residue and manure to conserve water and enhance nutrient availability and pearl millet yields in an arid tropical region. Soil \& Tillage Research 41,1997, pp. 43-51.

[19] Vallis I., Parton W.J., Keating B.A., Wood A.W. Simulation of the effects of trash and N fertilizer management on soil organic matter levels and yields of sugarcane. Soil \& Tillage Research 38: 1996, pp. 115-132.

[20] IPCC 2014, Revised Supplementary Methods and Good Practice Guidance Arising from the Kyoto Protocol, Hiraishi, T., Krug, T., Tanabe, K., Srivastava, N., Baasansuren, J., Fukuda, M. and Troxler, T.G. (eds) Published: IPCC, Switzerland. 